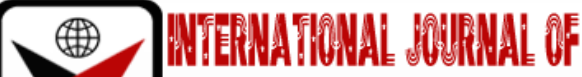

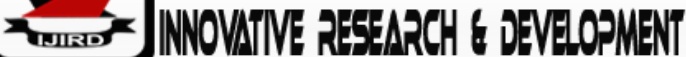

ISSN 2278-0211 (Online)

\section{An Evaluation of the Implementation of Strategic Planning as a Tool for Improving Performance Management Practices by Principals of Public Secondary Schools in Nyamira County, Kenya}

\begin{tabular}{c}
\hline Sylvans Seje \\
Doctoral Candidate, Educational Management, \\
Maasai Mara University, Narok, Kenya \\
Dr. Jane Ombati \\
Lecturer, Department of Languages, Literature and Culture, \\
Maasai Mara University, Narok, Kenya \\
Dr. Paul Maithya \\
Lecturer, Department of Curriculum Instruction and Educational Management, \\
Maasai Mara University, Narok, Kenya
\end{tabular}

\begin{abstract}
:
In recent years, strategic planning has been adopted by many organizations as a vital tool for improving performance with remarkable results. Performing organizations rely heavily on the strategies put in place and how well the strategies are implemented to improve performance. Educational institutions have equally adopted the concept of strategic planning to give their schools strategic direction for continuous improvement. Preparation of strategic plans by schools has therefore been seen as a roadmap that schools would follow to achieve desired levels in performance management practices. This study examined the extent to which the strategic plans had been implemented by the Principals, the challenges encountered in the process of implementation, and how this affected performance improvement practices in public secondary schools in Nyamira County, Kenya. The study used descriptive survey design and involved use of both primary and secondary data. The study targeted 45 Principals, 45 Deputy Principals and 135 Heads of Departments of selected secondary schools giving a total of 225 subjects. Stratified sampling was used to group the subjects while simple random sampling was used to select the participants from each stratum. Purposive sampling was used to select the Principals while Slovin formula was used to select Heads of Departments. Questionnaires were used for collecting data from the Principals, Deputy Principals and HODs. The Statistical Package for Social Sciences (SPSS)22.0 was used to analyse quantitative data. The findings of the study revealed that although strategic plans were available in all the schools with clear strategy implementation designs and structures, the implementation levels of the strategic plan were low, weak and ineffective and this adversely affected improvement in performance management practices, which was still below the desired levels in most schools. There were no clear tailor-made programmes to effectively implement the strategies and the implementation processes of the strategic planning as a tool faced many constraints resulting from inadequate funding, weak control and evaluation structures; lack of training, BOM, sponsor and community influence which negatively affected strategy implementation in most schools and hence hindered performance management improvement in most areas. The study recommended that there is a need to strengthen strategic planning implementation processes and provision of adequate funding by the government and parents to facilitate effective implementation. Regular visits, assessment, auditing and supervision should be intensified by education officials to ensure compliance, prudent use of school funds and effective implementation of strategic plans to improve performance.
\end{abstract}

Keywords: Evaluation, implementation, strategic planning, improvement, performance management practices, public secondary schools

\section{Introduction}

The concept of performance has become a key element in the success of organizations in the world today and this entirely depends on the structures put in place for continuous improvement. According to Evans (2003), in recent years, strategic planning theory in schools has moved away from the traditional business model towards a 'strategic thinking' approach. The strategic plan arises from pragmatic, flexible strategic thinking that relies on judgment as much as on 
spelling out action steps and the measurement of benchmarks. According to Briscoe \& Claus (2008), performance management is the system through which organization set work goals, determine performance standards, assign and evaluate employees' work, provide performance feedback to employees, determine training and development needs and distribute rewards to employees. Ong, (2019) states that strategic plan defines how success is measured. In order to achieve success, it's important to know what success means. A school with a strategy can monitors its progress toward key outcomes and evaluate where and how it may have gotten off track and that strategic plan aids a school's board with governance decisions and provides direction for the future. With a plan in place, the board has a roadmap which it can track, evaluate and modify to facilitate better governance decisions and provide direction for the future of the school.

Olsen (2012), states that a strategic plan is the formalized road map that describes how your company executes the chosen strategy. A plan spells out where an organization is going over the next year or more and how it's going to get there. Typically, the plan is organization-wide or focused on a major function, such as a division or a department. A strategic plan is a management tool that serves the purpose of helping an organization do a better job, because a plan focuses the energy, resources, and time of everyone in the organization in the same direction. SPtherefore helps build your competitive advantage, communicates your strategy to staff, prioritizes your financial needs, and provides focus and direction to move from plan to action. Strategic plans are often accompanied by parallel implementation plans which outline responsibilities, timelines, resource requirements and organizational or operational changes required in order to deliver on strategic plan activities.

The main idea behind the development of strategic plans is performance improvement that creates competitive advantage. The improvement in performance leads to achievement of desired results but this depends on how well the strategic decisions are implemented or executed as noted by Nielsen (2013) that in the public sector, the effects of performance management systems have differed from positive to negative, suggesting that differences in the characteristics of performance management systems and the contexts in which they are implemented play an important role in the success or failure of performance management. This implies that good strategy implementation is likely to lead to improvement and results desired while poor strategy implementation is likely to lead to underperformance and dismal results. Preparation of strategic plans by schools and effective implementation of strategy designs and decisions was therefore seen as a roadmap that schools would use to achieve desired levels in performance management.

In USA, Strategic planning follows a four-step process for planning a school wide programme, conducting a comprehensive needs assessment, managing the inquiry process, designing the school wide programme, and evaluating the programme (Cook, 2006). Lawrence (2001) argues that in developing countries, strategic planning attempts to promote school development by assessing the current state of the school development plan and providing information about it, increasing the overall rate of development, carrying out special types of programme and trying to improve the coordination between different stages of the planning process. He further states that that the main problem lies with the implementation of these strategic plans.

Strategic planning in Kenyan schools 'dates back to 2012 when the Ministry of Education in partnership with United States Agency for International Development (USAID), having identified performance management gaps in secondary schools developed Devolved Education Management Activity (DEMA) to train school managers on strategic planning as a reform tool in education at school level to improve- performance based management. The programme was implemented by Center for British Teachers (CfBT) now Education Trust (USAID 2013). According to DEMA, strategic planning was identified as a significant step towards the realization of improved performance-based management in secondary schools. The primary objective was to improve the quality of administration and performance management levels in line with current approaches and trends in education. To achieve this, training of school managers in strategic planning was therefore necessary as argued by (Hewlett, 2004) who asserts that effective institutional planning requires appropriate management and teacher training to steer the educational institution in the right direction. The DEMA training was a five-year programme from 2010 to 2014 in which districts and schools were trained on strategic planning and performance-based management.

Before 2012, most public secondary schools in Kenya had not embraced the concept of strategic planning, and this was seen as one of the shortcomings in the effective management of schools in the country. (Ngware, M.W. Wamukuru, D. K. \&Odebero, S. 0).

Development of strategic planning by schools was a significant step towards continuous improvement and achievement of strategic goals and objectives, but this depended on how well the strategies were executed as seen by Olsen, (2012) who states that strategic plans are often accompanied by parallel implementation plans which outline responsibilities, timelines, resource requirements and organizational or operational changes required in order to deliver on strategic plan activities. Wanjala and Rarieya (2014) in their study on strategic planning in schools in Kenya found out that there was evidence of the myriad challenges that strategic planning in schools in the country still faced. The study identified factors that had facilitated or hindered schools' engagement in strategic planning and which all originate from both within and outside the schools. The study also clearly demonstrated two important things. First, leadership as pivotal to the successful implementation of strategic planning and second, due to contextual challenges presented to schools in Kenya, a more creative and innovative approach to strategic planning needed to be adopted by the country's schools. This indicates that although the schools had developed the strategic plans, there were notable weaknesses in the implementation of strategic planning and this adversely affected performance management improvement of schools.

This paper examined the extent to which the strategic plans had been implemented by the Principals and the challenges encountered in the process of implementation, and how this affected performance improvement practices in public secondary schools in Nyamira County, Kenya. 
The development of strategic plans by schools was seen as a significant step towards improving performance. After the development of strategic plans, the next important step is to implement the strategic plans toput in practice strategic designs and decisions meant to improve performance. However, the Ministry of Education standards assessment reports 2014-2016 revealed that there were notable weaknesses in implementation of strategic plans by Principals of public secondary schools in Nyamira County and this continued to affect improvement of performance management practices which was still below the expected levels. This study therefore sought to find out why despite the training in Strategic planning, available resources and manpower, the school Principals were still recording low levels of achievement and finding it difficult to effectively implement the strategic plans to improve performance practices

The objectives of the study were to explore the levels of the implementation of strategic planning as a tool for improving performance management practices by principals of public secondary schools in Nyamira County, and to identify challenges that affect implementation of strategic plans as a tool for improving performance. The significance of the study was that the study would provide valuable insights to stakeholders in the education on successful implementation of strategic planning in educational institutions and how the benefits may improve performance management practices to help the schools realise their strategic goals and objectives. It would also help in identifying challenges encountered during the implementation of strategic plans implementation and the remedies that can be put in place to make the schools achieve desired levels in performance management practices. Data from these findings could provide the Ministry of Education with useful information on how effective implementation of strategic planning can improve performance practices.

\section{Literature Review}

Successful implementation of strategic planning comes with many benefits. Several studies have been conducted that have emphasized strategic planning as a tool to guide schools performance management improvement. Maleka (2014) states that strategy implementation is putting the actual strategy into practice to meet organizational goals. The idea behind this concept is to gather all the available and necessary resources required to bring the strategic plan to life. Organizations implement strategies through creating budgets, programs and policies to meet financial, management, human resources and operational goals. For the successful implementation of a strategic plan, cooperation between management and other personnel is absolutely necessary.

Ong, (2018) argues that successful strategic plan implementation requires proper management of budgetary and time resources, the creation of high-output teams and the consistent monitoring of all progresses. The strategic planning in a school set up therefore determines the success of a school in management and performance. Strategic planning provides a framework in which the most important priority of the school - Students' educational achievement is taken care of. This is in agreement with a study by (Katheren, 2003) who argued that in essence, strategic planning process help leaders to think and act strategically, develop effective strategies, clarify future directions for the organization, establish priorities and establish teamwork to improve performance. Consequently, it's viewed as critical in times of change in school leadership by keeping the organization focused yet flexible to meet the dynamics of the modern society. In such circumstances, organizational stability is enhanced because established committees still serve as the organizational memory in focusing on the future.

Olsen (2012), states that a strategic plan is the formalized road map that describes how your company executes the chosen strategy. A plan spells out where an organization is going over the next year or more and how it's going to get there. Typically, the plan is organization-wide or focused on a major function, such as a division or a department. Strategic plans are often accompanied by parallel implementation plans which outline responsibilities, timelines, resource requirements and organizational or operational changes required in order to deliver on strategic plan activities. Olsen (2013) further asserts that some of the benefits that may occur as a result of implementation of strategic planning: makes the management of an organization easier by providing a framework and a clearly defined direction for decision-making, establishes a uniform vision and purpose that is shared among all members of the organization and helps them pull in the same direction, works to create an increased level of commitment to the organization and its goals, can result in improved quality of services for clients and a means of measuring the service.

According to ECRA whitepaper (2015), Strategic planning provides understanding on how schools work, gives insights on how finances are spent, identifies needs of stakeholders and gives an opportunity to set specific data-driven priorities. Involvement of stakeholders especially at implementation stage creates synergy. It brings onboard partners from private sector to finance vocational programs and general infrastructure. Learners' participation is of great importance as their views can help the management in establishment of priority areas in organizational development. As a result, the achievement of strategic planning's performance and excellence in academics, arts and aesthetics making it worth the effort. Strategic plans allow school management to articulate clear goals and objectives for improving teaching and learning. It's also believed to enhance a healthy working relationship with the community, and elect officials who support education making implementation smooth. Evidently, strategic planning entails reforming relationship of accountability among various stakeholders and participants in the education sector so that responsibilities are clear, measured, monitored and supported. It is accompanied by clear feedback cycle between financiers, strategy implementers and beneficiaries.

Ivan W. (2016), states that strategic planning is important to an organization because it provides a sense of direction and outlines measurable goals. Strategic planning is a tool that is useful for guiding day-to-day decisions and also for evaluating progress and changing approaches when moving forward.

Alves (2011) mentions the advantages of strategic planning: accelerate decisions, to improve the internal communication, to increase the managerial capacity to make decisions, to provide an integrated vision of the organization, 
to increase the delegation, to improve programs of the quality and to define an only direction for all (employees, shareholders, community and customers). A strategic plan is a long-term plan of action designed by the top management of a school including all educational stokeholds to achieve a particular goal or objective as differentiated from tactics or immediate actions where resources at hand either financial or human or both. Strategic planning is a tool that is useful for guiding day-to-day decisions and also for evaluating progress and changing approaches when moving forward. Devra (2018).

According to Glen (2011), performance management provides mechanisms for increasing the probability of success and to generate the data necessary to provide actionable information to the decision makers. 1 . Know where you are going by defining 'done' at some point in the future,how much time and money is needed to reach the destination,identify the impediments to progress along the way to the destination, have some means of removing, avoiding, or ignoring these impediments, and have some ways to measure your planned progress, not just your progress. Robert (2011)opines that performance management takes on a new meaning when brought up in the context of organization strategy. To fully understand the term in a strategic setting, we must first understand what successful strategy management involves. Ultimately, successful strategy management involves achieving an organization's predetermined vision and goals as stated in their strategic plan. The process of how they go about achieving these desired outcomes is what we call performance management. So, how is this different from the employee-based performance management? Well, it's important to note that performance management in the context of strategy is strictly referring to the performance related to execution of the organization's strategy. In comparing the organization's 'actual results' against its 'desired results. 'When the actual results aren't meeting the desired results, then a 'performance improvement zone exists.' Those in charge of executing the strategy are then responsible for making adjustments in the strategic operating plan to address unsatisfactory performance. Performance management is critical to successfully executing an effective organizational strategy. It requires a commitment from those in charge of strategy to continuously monitor and analyze how each area of the organization is performing compared to expectations. For many leadership teams, this commitment is easier said than done.

The above studies addressed the advantages and the benefits of having a strategic plan in theory but in practice, there are no literature that indicates how the strategic plans have actually been implemented and if they have produced the desired results and benefits. This study filled the gap by examining the actual implementation levels of the strategic plans in schools and if they were producing the intended results.

\section{Theoretical Framework}

\subsection{Quantitative Management Theory}

This study was based on Quantitative Management Theory. According to Hodgetts, (1990)'The Quantitative School, which is also called Management Science School, consists of those theorists who see management as a body of quantitative tools and methodologies designed to aid today's manager in making the complex decisions related to operations and productions. It emphasizes the use of mathematical and statistical techniques in management and focuses on finding right answers to managerial problems, which are solved through decision making. The customers' attitudes, ideas, assessment and familiar use of certain goods or products can be mathematically calculated and quantified. In other words, this theory advocates the use of mathematical procedures to management problems. The study was based on the level of achievement of institution's strategic goals which were assumed to be specific and measurable. These goals can be reached when optimal decisions are needed to be made through formal scientific reasoning backed by quantification. Decisions are based on data and logic rather than intuition and judgment. Statistical data was, therefore, very crucial in determining how strategic planning had been implemented and used as a reform tool in improving performance management practices in secondary schools in Nyamira County, Kenya.

\section{Methodology}

A descriptive survey design was used in this study. A research design is the main plan used by the researcher that provides solution to the four issues; what questions, relevance, data collection and analysis of the findings (Yin, 2003). Creswell (2004) posits that there are two general types of methodology called qualitative and quantitative research methods.

Mulusa (1999) suggest that one-third of the target population is representative enough to make an estimate of characteristics being investigated; therefore, the sample of public schools which were studied was based on one third of the target population. A sample is a small group obtained from the available population, Mugenda and Mugenda (2003).

135 public secondary schools in Nyamira County were selected for the study. One-third of 135 gave a sample size of 45 schools accounting for 33 percent of the target population. Stratified sampling method was then applied and this involved dividing population into different subgroups (strata). The respondents were selected by dividing population (135) into Boys' Boarding, Girls' Boarding, Mixed Day and Mixed Day and Boarding secondary schools in order to achieve equal representation of both categories in the sample group. Lottery technique was used to select the 45 schools which were sampled in each category. Purposive sampling was then used to select the 45 Principals, 45 Deputy Principals. Simple random sampling was used to select 3 HODs per school. The population of the study therefore consisted of 315 respondents. 


\section{Results}

\subsection{Status of Strategic Planning Implementation in Schools}

\begin{tabular}{|c|c|c|c|c|c|c|c|c|}
\hline \multirow{2}{*}{$\begin{array}{c}\text { Levels of Strategic Plan } \\
\text { Implementation }\end{array}$} & $\begin{array}{c}\text { S A } \\
\mathbf{4}\end{array}$ & $\mathbf{A}$ & $\mathbf{3}$ & $\mathbf{2}$ & $\mathbf{S ~ D}$ & Total & Mean & $\begin{array}{c}\text { Weighted } \\
\text { Mean }\end{array}$ \\
\hline \multirow{2}{*}{ Principals } & Freq. & 0 & 4 & 22 & 19 & 45 & 1.67 & 2.5 \\
\cline { 2 - 10 } & $\%$ & 0 & 8.9 & 48.9 & 42.2 & 100 & & \\
\hline \multirow{2}{*}{ D/Principals } & Freq. & 0 & 5 & 27 & 13 & 45 & 1.82 & 2.5 \\
\cline { 2 - 10 } & $\%$ & 0 & 11.1 & 60.0 & 28.9 & 100 & & \\
\hline \multirow{2}{*}{ HODs } & Freq & 0 & 23 & 99 & 13 & 135 & 2.07 & 2.5 \\
\cline { 2 - 9 } & $\%$ & 0 & 17.0 & 73.3 & 9.6 & 100 & & \\
\hline
\end{tabular}

Table 1: Strategic Plan Implementation Levels

As indicated in table 1, the results show that 91.1 percent of the responses from Principals indicated ineffectiveness in strategic plan implementation. This was further supported by 88.9 percent responses from the Deputy Principals, 82.9 percent responses from the Heads of Departments, 88.9 percent chairpersons of Board of Management and similarly 88.9 percent responses from PA chairpersons, expressing disagreement with the statement that there was effective implementation of strategic plans by the school management. This indicated that the levels of implementations were low and unsatisfactory, meaning that although there were clear implementation structures in the school's strategic plans' designs, most schools did not effectively implement strategies designed to improve performance management practices, and that performance improvement work plans in the schools had not been developed to effectively implement the strategies. Strategic plan implementation was therefore weak and ineffective.

\begin{tabular}{|c|c|c|}
\hline Source of Income & \multicolumn{2}{|c|}{$\begin{array}{c}\text { Responses } \\
\text { Frequency Percentage }\end{array}$} \\
\hline Government & 315 & 30.67 \\
\hline Parents & 315 & 30.67 \\
\hline School IGA & 40 & 3.90 \\
\hline Bank loan & 24 & 2.34 \\
\hline Sponsors & 10 & 0.97 \\
\hline CDF & 315 & 30.67 \\
\hline Donors & 8 & 0.78 \\
\hline Total & 1027 & 100 \\
\hline
\end{tabular}

Table 2: Sources of School Funding for Implementation of School Programs Source: Author 2018

Data from Table 2 above revealed the types of funding received by the schools. The respondents indicated that 30.67 percent the funds received by the schools came from the government through Tuition Free Day Secondary funds and grants, and a similar 30.67 percent from PA/Parents in form of school fees and another 30.67 percent from CDF. Only 2.34 percent of the funds were borrowed from the banks by few schools in form of loans, and 3.90 percent of the funds came from the school income generating activities, meaning that very few schools had in place IGAs. Sponsors and donors were the least contributors at 0.98 and 0.78 percent respectively. This meant that the main sources of income for the schools came from Government, PA/Parents and CDF. Only few schools secured loans from the banks and donor funding while the sponsors played minimal role in provision of funding to the schools. Most schools did not engage in income generating activities as an alternative source of additional funding to the schools. To effectively implement the school programs from the strategic plans, funding is a necessity. Effective implementation of the strategic plan requires funding and all the respondents identified the source of school funding as the Government of Kenya, parents, IGA, Bank loan, Sponsors, and $\mathrm{CDF}$. To a given extent therefore, the schools had some funding available to implement the strategic plans and other school programs.

\begin{tabular}{|c|c|c|c|c|c|c|c|c|}
\hline $\begin{array}{c}\text { Adequacy of School } \\
\text { Funds }\end{array}$ & \multicolumn{2}{|c|}{$\begin{array}{c}\text { Extremely } \\
\text { Adequate }\end{array}$} & \multicolumn{2}{|c|}{ Very Adequate } & \multicolumn{2}{c|}{ Adequate } & \multicolumn{3}{c|}{ Inadequate } \\
\hline & Freq & $\%$ & Freq & $\%$ & Freq & $\%$ & Freq & $\%$ \\
\hline Government & 0 & 0 & 0 & 0 & 10 & 3.17 & 305 & 96.82 \\
\hline PA/Parents & 0 & 0 & 0 & 0 & 30 & 9.52 & 285 & 90.47 \\
\hline School IGA & 0 & 0 & 0 & 0 & 5 & 1.58 & 310 & 98.41 \\
\hline Bank loan & 0 & 0 & 0 & 0 & 5 & 1.58 & 310 & 98.41 \\
\hline Sponsors & 0 & 0 & 0 & 0 & 2 & 0.63 & 313 & 99.37 \\
\hline CDF & 0 & 0 & 0 & 0 & 81 & 25.71 & 234 & 74.28 \\
Donors & 0 & 0 & 0 & 0 & 0 & 0 & 315 & 100 \\
\hline
\end{tabular}


Results from table 4.9 above shows that 96.82 percent of the respondents indicated that funds from the government were inadequate while 3.17 percent indicated that funds from the government were adequate. The researcher also established from BOM/PA interview that although the government through the Ministry of Education provided money to schools as TFDSS fund, these were inadequate to meet the financial needs of the schools as per their strategic plans and financial needs. Funds provided by parents in form of school fees to supplement the TFDSS were also noted to be inadequate as indicated by 90.4 percent of the respondents as development fees had been put on hold by the MOE.

1.58 percent of the respondents reported that funds from school income generating activities were adequate; while 98.41 percent indicated that they were inadequate meaning that even for the schools with IGAs, the funds generated from such enterprises were not enough to meet their financial needs.

Only 1.58 percent of the respondents reported that school funds from sponsor were adequate while 98.46 percent reported that they were inadequate meaning that to a large extent, sponsors did not play a significant role in providing funds to the schools. 25.71 percent of respondents reported that funds from CDF were adequate; while 74.28 percent of the respondents indicated that they were inadequate, meaning that in some instances, some projects funded by CDF were completed while in many cases the funds provided were not enough to complete the projects initiated by CDF. This was attributed to changes in leadership after general elections and the complexities that arise when the incumbent loses the parliamentary seat. It was observed that most donors did not give funds to the schools directly, but partially supported some development projects within the schools that happened to have been identified by the said donors to benefit from the same.

Inadequacy of funds therefore hindered and slowed down the school's implementation programmes, hence affecting the achievements of goals and objectives put in place to improve performance management practices. This meant that in most schools, the funds provided were not enough to adequately facilitate the full implementation of the strategic plans. The findings therefore were consistent with Ong (2018), whose study found out that successful strategic plan implementation requires proper management of budgetary and time resources, the creation of high-output teams and the consistent monitoring of all progress. The strategic planning in a school set up therefore determines the success of a school in management and performance. Strategic planning provides a framework in which the most important priority of the school - Students' educational achievement is taken care of. The findings are in agreement with a study by Catherine Catherine, Emily, Jane. (2015), who found that that strategic planning in schools is greatly hindered by inadequate resources in terms of physical facilities, finances and human resources; that ignorance of existing policies, high headship turnsover and lack of training hinders strategic planning in schools.

\begin{tabular}{|c|c|c|c|c|c|c|c|c|}
\hline \multicolumn{2}{|c|}{$\begin{array}{c}\text { Challenges to Strategic } \\
\text { Plan Implementation on } \\
\text { Performance } \\
\text { Improvement Practices }\end{array}$} & $\begin{array}{c}\text { S A } \\
4\end{array}$ & $\begin{array}{l}\mathbf{A} \\
\mathbf{3}\end{array}$ & $\begin{array}{l}\text { D } \\
2\end{array}$ & $\begin{array}{c}\text { S D } \\
1\end{array}$ & Total & Mean & $\begin{array}{l}\text { Weighted } \\
\text { Mean }\end{array}$ \\
\hline \multirow[t]{2}{*}{ Principals } & Freq. & 11 & 33 & 1 & 0 & 45 & 3.22 & 2.5 \\
\hline & $\%$ & 24.4 & 73.3 & 2.3 & 0 & 100 & & \\
\hline \multirow[t]{2}{*}{ D/Principals } & Freq. & 6 & 36 & 3 & 0 & 45 & 3.07 & 2.5 \\
\hline & $\%$ & 13.3 & 80.0 & 6.7 & 0 & 100 & & \\
\hline \multirow[t]{2}{*}{ HODs } & Freq & 0 & 103 & 7 & 0 & 135 & 3.13 & 2.5 \\
\hline & $\%$ & 0 & 76.3 & 5.2 & 0 & 100 & & \\
\hline
\end{tabular}

Table 4: Challenges in the Implementation of Strategic Plan

Results from Table 10 above indicates that there were challenges encountered by school managers in the process of implementing strategic plan with 97.7 percent of the Principals agreeing that the schools faced challenges in the implementation of strategic plans to improve performance management practices. This was supported by 93.3 percent responses from deputy Principal, 76.3 percent responses from HODs, 91.2percent responses from Board of Management chairpersons and 95.5 percent responses from Parents Association chairpersons, meaning that the challenges experienced in the process of strategic plan implementation by school managers were many. This indicated that the challenges as noted to a great extent affected the implementation of strategic plan in schools and therefore impacting negatively in the improvement of performance management practices. The findings are in agreement with a study by Conley (1993) who argued that strategic planning in schools faces challenges because a number of school leaders lack knowledge of the strategic planning processes as well as of how toconvert strategic plans into action plans for effective implementation. This is also in agreement with Wanjala and Rarieya (2014) in their study on strategic planning in schools in Kenya found out that there was evidence of the myriad challenges that strategic planning in schools in the country still faced. 


\begin{tabular}{|c|c|c|c|c|c|c|}
\hline \multicolumn{2}{|c|}{$\begin{array}{c}\text { Constraints to } \\
\text { Effective Strategic } \\
\text { Plan Implementation }\end{array}$} & \multirow{2}{*}{$\begin{array}{c}\begin{array}{c}\text { Inadequate } \\
\text { Funding }\end{array} \\
45 \\
\end{array}$} & \multirow{2}{*}{$\begin{array}{c}\text { Misuse of } \\
\text { Funds } \\
26\end{array}$} & \multirow{2}{*}{$\begin{array}{c}\text { Lack of Technical } \\
\text { Skills/Training in } \\
\text { Strategic Planning } \\
38\end{array}$} & \multirow{2}{*}{$\begin{array}{c}\text { Interference from Some } \\
\text { BOM/Sponsor and } \\
\text { Community Members }\end{array}$} & \multirow{2}{*}{$\begin{array}{c}\text { Total } \\
45 \\
\end{array}$} \\
\hline Principals & Freq. & & & & & \\
\hline & $\%$ & 100 & 57.8 & 84.4 & 71.1 & \\
\hline \multirow[t]{2}{*}{ D/Principals } & Freq. & 45 & 45 & 36 & 35 & 45 \\
\hline & $\%$ & 100 & 100 & 80.0 & 77.8 & \\
\hline \multirow[t]{2}{*}{ HODs } & Freq & 135 & 135 & 111 & 98 & 135 \\
\hline & $\%$ & 100 & 100 & 82.2 & 72.6 & \\
\hline
\end{tabular}

Table 5: Constraints to Effective Strategic Plan Implementation

The analysis of data presented in Table 11 above on constraints to effective implementation of strategic plans reflected the following percentage points: Inadequate funding (100\%), Misuse of funds (57.8\%-100\%), lack of technical skills /training (80.0\%-84.4\%) interference from some BOM, Community and Sponsors (71.1-77.8\%). These indicated that effective strategic planning implementation was constrained by inadequate funding (100\%), Misuse of funds (85.93\%), Lack of technical skills and training (82.2\%) and interference from some BOM, Community, and Sponsors (73.83\%). This meant that in most schools, achievement of desired improvement in performance management practices could not be realized due to the identified constraints which were impediments in the implementation of strategic plans.

Inadequate funding was therefore one of the identified constraints that was affecting the levels strategic plan implementation. The implication was that, for strategy implementation to succeed, adequate funding must be provided; prioritization and prudent use of funds must be taken into consideration. The findings were consistent with Hayward, (2008) whose study on the challenges of strategic planning in higher education in developing countries suggests that institutions in these contexts find it challenging to engage in the process because of two reasons: limited financial resources and high competition for the scarce resources available. Conley (1993) argues that strategic planning does not provide the financial resource deficit that accrues from mapping out strategies required for improvement, thereby making implementation a challenge.

The second constraint identified to be affecting implementation of strategic plans was improper use of school funds as attested to by 57.8 percent of the Principals, 100 percent of the Deputy Principals and 100percent of the Heads of Departments, meaning that the funds received by the schools were not prudently used or were not used for the intended purposes, meaning that the funds received were not well used. Majority of the Principals, who are the managers of school funds, also contended that the funds received were not properly used, but 42.2 percent of the Principals indicated that the funds received were well used.

Most schools also had uncollected fees of between nine hundred thousand and four million Kenya shillings over the years. This pointed out to problems in receipt, collection and management of school funds this was likely to affect improvement of performance management practices in many departments. This was in agreement with some studies which attributed the challenge of financing in secondary schools to poor governance and management of the available resources (Mulkeen 2007; Rarieya 2007; Onguko et al. 2008; World Bank 2008).

The third constraint identified was lack of technical skills in strategic planning attested to by 84.4 percent of the Principals, 80 percent of the Deputy Principals and 82.2 percent of the Heads of Department. Some of the schools' personnel were still lacking technical skills in strategic planning and all these led to poor strategy implementation, strategy control and evaluation due to lack of proper training.

This implies that training is a very important component in strategic planning; teachers and managers therefore must be trained as they play a key role in the planning, implementation, control and evaluation processes of strategic planning and requires appropriate training to equip them with relevant technical skills in strategic planning to enable them effectively improve performance.

The findings are in agreement with a study by Catherine et.al (2015), who found that most school leaders lacked relevant skills, leadership qualities and commitment to strategic planning, meaning that training is strategic planning is necessary for all school's managers and stakeholders as noted by Hewlett (2004) who asserts that effective institutional planning requires appropriate management and teacher training to steer the educational institution in the right direction. This is also in agreement with Cook (2010) who asserted that training in strategic planning is very important to the management and development of strategic planning in schools. This also resonates with a study by Davies (2006) who found that the actual strategic planning phase is technical and demands training in skills and know-how to successfully carry out the process.

The fourth constraint identified was interference by some Board of Management, Sponsor and community as indicated by 71.1 percent of the principals, 77.8 of the deputy Principals and 72.6 Heads of departments, these were constraints to strategy implementation in most schools, meaning that some schools were experiencing management problems due to BOM, sponsor and community politics.The BOM, Sponsor and Community influence were based on vested interests, difference between the principal and some BOM members; some sponsors were demanding that principals heading their schools must be those belonging to the sponsoring faith; and communities also demanding that those heading their schools must belong to the clans where the schools were located. This was an impediment to successful implementation of strategic plans in schools which school created a big conflict with the interests and needs of the 
learners, school programmes and documented government policies, greatly affecting strategy implementation in some schools and hence affecting performance management practices.

The findings concur with a study by Maleka (2014) who found out that strategy implementation is putting the actual strategy into practice to meet organizational goals. For the successful implementation of a strategic plan, cooperation between management and other personnel is absolutely necessary. The findings are also in agreement with Ong, (2018) who states that successful strategic plan implementation requires the creation of high-output teams and the consistent monitoring of all progresses.

The constraints identified undermined the achievement of goals and objectives meant to improve performance in the secondary schools and this explains why it was still difficult for the schools to achieve the desired results in performance.

\section{Discussion of Findings}

The findings revealed that although strategic plans were available in all the schools with clear strategy implementation designs and structures, most principals did not effectively implement their schools' strategic plans. The implementation levels of the strategic plan were low, ineffective, weak and below the desired levels in most schools.The respondents expressed dissatisfaction in the effectiveness of strategic plan implementation in the schools meaning that performance management improvement matrix and structures based on the schools' strategy implementation designs and decisions were ignored, and thatthere were no clear tailor-made programmes to effectively implement the strategies. Funds received by the schools were not well used, meaning that in most schools, prioritized needs were ignored and disregarded in favor of individual interests.

The study also established that some school administrators lacked technical competencies to effectively implement in improvement strategies, and this therefore affected improvement of performance management practices levels in most schools. The influence of the sponsors and the community interests created a big conflict with the needs of the learners, school programmes and documented government policies, interfering with strategy implementation in some schools and hence affecting improvement of performance management practices. For successful strategy implementation, stakeholders need to work together, minimize conflicts in order to help the schools achieve their strategic goals and objectives in improving performance management practices. Lack of commitment and team work in the management of the schools was therefore a big impediment to effective implementation of strategic planning as an improvement tool in most schools.

\section{Conclusion}

Most schools were still experiencing difficulties in achieving improvement to the desired levels of performance management due to weaknesses in the implementation of strategic plans as a performance improvement tool. The implementation of programs in the schools therefore had little or no connection to strategic planning as the schools lacked performance measurement tools that would show the levels of implementation achieved in relation to strategic plans. The implementation processes of the strategic planning as a performance improvement tool faced by many constraints resulting from inadequate funding, weak control and evaluation structures; BOM, sponsor and community influence, all of which negatively affected strategy implementation in most schools hence hindered performance management improvement in most schools.

\section{Recommendations}

- The Ministry of Education, BOM and Parents should provide or source for adequate funding for infrastructural development to facilitate school administrators implement strategic plans and acquire further training to improve their skills in strategic planning for effective implementation. Careful consideration should also be given to other sources of funding by school managers such as donors, CDF and County government that would ensure provision of adequate funding to implement the strategic plans. This would in turn facilitate performance improvement programs

- The school mangers should exhibit selflessness to ensure prudent use of funds, put aside vested interests and strictly adhere to schools' priorities as per the strategic plans. This is very necessary for effective implementation of strategies put in place to improve performance management in schools.

- Regular visits, assessment, auditing and supervision should be intensified by education officials to ensure compliance and effective implementation of strategic plans and performance improvement programmes.

- Sponsors and Community should apply due diligence in management of schools, respect and adhere to the Ministry of Education policies in school management to help the schools realize their strategic goals and objectives meant to improve performance to the desired levels.

\section{References}

i. Alves,L. H. Dias and Paula, S. Martins (2011),Model for Applying Strategic Planning in Educational Institutions: Universidade Federal de Juiz de Fora, MG - Brasil - POMS 23rd Annual Conference Chicago, Illinois, U.S.A. April 20 to April 23, 2011

ii. Catherine, J. Kiprop., Emily, J. Bomett., Jane, Jelimo Michael.(2015) Strategic Planning in Public Secondary Schools in Kenya: Challenges and Mitigations- International Journal of Advanced Research in Education \& Technology (IJARET) 52 Vol. 2, Issue 4 (Oct. - Dec. 2015) ISSN : 2394-2975 
iii. Conley, D. (1993), Strategic Planning in Practice: An Analysis of Purposes, Goals, and Procedures, paper presented at the Annual Meeting of the American Educational Research Association, Atlanta, April.

iv. Cook, W.J., (2006) Strategies. The Art and Sciences of Holistic Strategy. London: Quarum Books Westport, Connectcut.

v. Creswell, J., (2004). Qualitative Inquiry and Research Design: Choosing Among Five Approaches. Thousand Oaks, CA: Sage Publications.

vi. Denis R, Briscoe and Lisbeth, Claus (2008) Employee Performance Management: Policies and Practices: A Global Perspective DOI:10.4324/9708203885673-2 book Performance Management Systems

vii. DevraGartenstein (2019). Why is Strategic Planning important to an Organization? Retrieved from https://smallbusiness.chron.com

viii. ECRA White paper. Creating the Future: Strategic Planning for schools pdf Retrieved January 2015.

ix. Evans, R. (2007), the Case against Strategic Planning, Independent School, fall 2007.

x. Fonseca, M. (2003). BRASIL. Ministério da Educação e Cultura. O Plano de Desenvolvimento da Educação: razões, princípios e programmemeas. Brasília, DF, 2007.

xi. Gay, l., Mills, G., \&Airasian, P. (2006), Educational Research: Competencies for Analysis and Application. (8th ed). Boston .Pearson Education

xii. Glen, B. Alleman. (2011) Performance based Management in a Nutshell. Niwotridge Consulting, 2011

xiii. Ivan Widjaya (2016) 7 reasons why Strategic Planning is Essential for Business success. Retrieved from https://www,noobpreneur.com

xiv. Katheren, P. (November, 2003). Strategic Planning in the University: University of Wisconsin System Board at www.QUALITY.WISC.EDU

xv. Lawrence, L. (2001). Reducing the Barriers to Expansion of Schools by Focusing on

xvi. School Development Plans. Emmerald Group Publishers.

xvii. Maleka, Stevens (2014): Strategic Management and Strategic Planning Process: South African Perspective , Conference Paper · March 2014

xviii. Mugenda, M.O.\&Mugenda, G.A. (1999). Research Methods: Quantitave and Qualitative approaches. Nairobi: ACTS Press

xix. Mulkeen, A. (2007), Recruiting, Retaining, and Retraining Secondary School Teachers and Principals in SubSaharan Africa (Washington, DC: World Bank).

xx. Nielsen, Poul A.(2013). Performance Management, Managerial Authority, and Public Service Performance. Journal of Public Administration Research and Theory. Published electronically on June 2. doi:10.1093/jopart/mut025.

xxi. Ngware, M.W. Wamukuru D. K. \&Odebero, S. O (2006). Total Quality Management of Secondary schools in Kenya: Extent of Practice, Quality Assurance in Education Vol. 14 no 4 pp 339-362

xxii. Olsen, Erica. (2012) Strategic Planning Kit for Dummies, 2nd Edition John Wiley \& Sons, Inc.

xxiii. Ong, Cara. (2018) Seven reasons why schools need Strategic and operational Plan. Retrieved from https://www.envisio.com

xxiv. Onguko, B., Abdalla, M., \& Webber, C.F. (2008) Mapping Principal Preparation in Kenya and Tanzania, Journal of Educational Administration 46(6): 715-726.

xxv. Richard M Hodgetts (1990) Management: theory, process, and practice. San Diego: Harcourt Brace Jovanovich, 1990. www.businessmanagementideas.com/management/...

xxvi. Robert, Bacal. (2011) Performance Management 2/E (Briefcase Books Series)

http://www.mmu.ac.uk/humanresources/policy/general.php

xxvii. Singleton Jr., R.A., \&Starits, B.C. (2005). Approaches to Social Research (4th Edition). New York, NY: Oxford University Press

xxviii. Wanjala, Christine. N, Rarieya, Jane. F. A. (2014) Strategic Planning in Schools in Kenya: Possibilities and Challenges https://www.researchgate.net/publication/268515695Article $\cdot$ April 2014

xxix. Yin, R. (2003).Case Study Research: Design and Methods, (3rd ed.). Thousand Oaks, CA: Sage Publications 